\title{
The shadow of vessels masquerading as a lung mass
}

\author{
Chih-Ming Lin, Ching Shiang Chen
}

Division of

Hepatogastroenterology, Department of Internal

Medicine, China Medical University Hospital, China

Medical University, Taichung, Taiwan

\section{Correspondence to}

Dr Ching Shiang Chen,

d13460@mail.cmuh.org.tw
To cite: Lin C-M, Chen CS. BMJ Case Reports Published online: 2 January 2013 doi:10.1136/bcr-2012007522

\section{DESCRIPTION}

A 72-year-old man reported tarry stool for a day in the emergency department of a hospital. It was diagnosed that he had colon adenocarcinoma, and underwent left hemicolectomy 3 years ago. He did not receive any chemotherapy. A routine chest $\mathrm{x}$-ray showed a round shadow in the upper lobe of his right lung (figure 1). He denied having fever, cough, shortness of breath or weight loss in the recent 2 months. Comparing the image with the one 2 years ago, we suspected that it might be recurrent colon cancer with metastasis of his right lung, enlarged mediastinal lymph nodes, lung tuberculosis, lymphoma or primary lung cancer. Surprisingly, the contrast-enhanced CT of chest revealed that this lesion was the shadow of distorted brachiocephalic artery and right common carotid artery (figure 2).

When reviewing the chest $\mathrm{x}$-ray again, we found that the latest one was anterioposterior view, and the patient rotated to the right side. This might result in magnifying the shadow of deformed vessels and make us misinterpret this image. In addition to chest CT scan, transthoracic sonography is another modality to investigate the suspected mass with wall contact in right upper lung. ${ }^{1}$ It is cheap, has no radiation exposure and easy access. ${ }^{2}$ The vessels can be distinguished easily from other solid tumour by colour Doppler sonography.

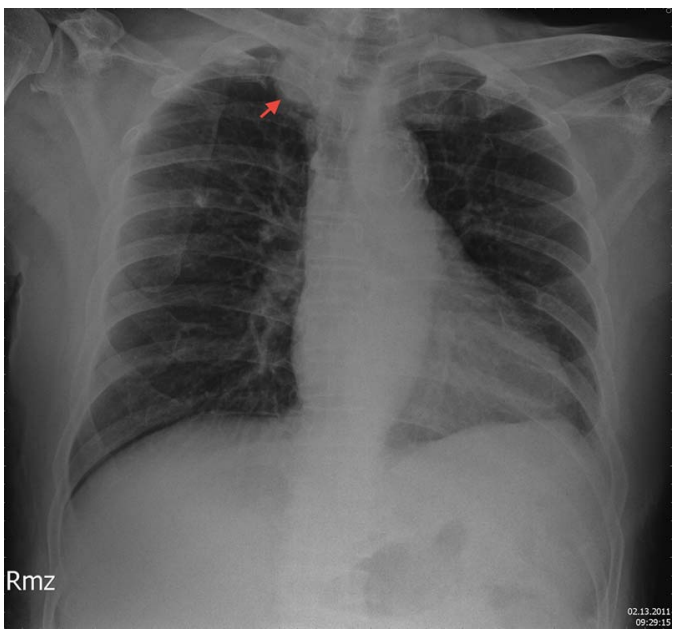

Figure 1 Chest x-ray: a round shadow in the upper lobe of right lung, near the clavicular head (red arrow).

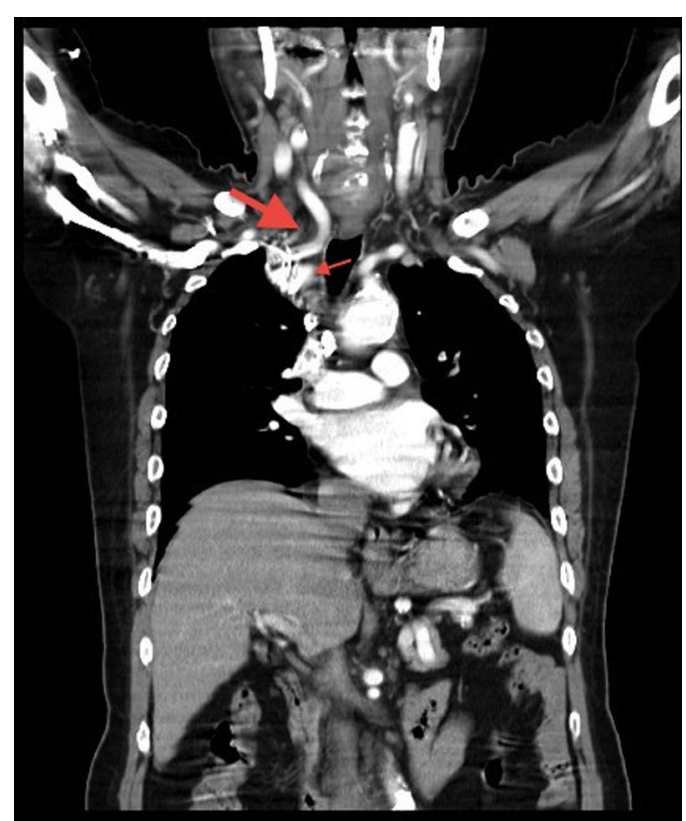

Figure 2 Contrast-enhanced chest CT scan: the round shadow is composed of distorted right common carotid artery (big red arrow) and brachiocephalic artery (small red arrow).

\section{Learning points}

- Before you read a chest $x$-ray, be sure to determine whether it is qualified.

- Sonograpy can be used to evaluate the suspected mass with wall contact in the lungs.

Competing interests None.

Patient consent Obtained.

\section{REFERENCES}

1 Chira R, Chira A, Mircea PA. Intrathoracic tumors in contact with the chest wall-ultrasonographic and computed tomography comparative evaluation. Med Ultrason 2012;14:115-19.

2 Koegelenberg CFN, Groote-Bidlingmaier von F, Bolliger CT. Transthoracic ultrasonography for the respiratory physician. Respiration 2012;84:337-50. 
Copyright 2013 BMJ Publishing Group. All rights reserved. For permission to reuse any of this content visit http://group.bmj.com/group/rights-licensing/permissions.

BMJ Case Report Fellows may re-use this article for personal use and teaching without any further permission.

Become a Fellow of BMJ Case Reports today and you can:

- Submit as many cases as you like

- Enjoy fast sympathetic peer review and rapid publication of accepted articles

- Access all the published articles

- Re-use any of the published material for personal use and teaching without further permission

For information on Institutional Fellowships contact consortiasales@bmjgroup.com

Visit casereports.bmj.com for more articles like this and to become a Fellow 